\title{
Norwegian Fascism in a Transnational Perspective: The Influence of German National Socialism and Italian Fascism on the Nasjonal Samling, 1933-1936
}

\author{
Martin Kristoffer Hamre \\ Humboldt University of Berlin and King's College London \\ martin@hamre.de
}

\begin{abstract}
Following the transnational turn within fascist studies, this paper examines the role German National Socialism and Italian Fascism played in the transformation of the Norwegian fascist party Nasjonal Samling in the years 1933-1936. It takes the rivalry of the two role models as the initial point and focusses on the reception of Italy and Germany in the party press of the Nasjonal Samling. The main topics of research are therefore the role of corporatism, the involvement in the organization CAUR and the increasing importance of anti-Semitism. One main argument is that both indirect and direct German influence on the Nasjonal Samling in autumn 1935 led to a radicalization of the party and the endorsement of anti-Semitic attitudes. However, the Nasjonal Samling under leader Vidkun Quisling never prioritized Italo-German rivalry as such. Instead, it perceived itself as an independent national movement in the common battle of a European-wide phenomenon against its arch-enemies: liberalism and communism.
\end{abstract}

\section{Keywords}

Norway - Germany - Italy - Fascism - National Socialism - transnational fascism Nasjonal Samling - Vidkun Quisling 
In October $1933^{1}$ - five months after the foundation of the party Nasjonal Samling [NS; National Unity $]^{2}$ - Norwegian merchant Johan Wilhelm Klüver sent a letter from Tientsin in China addressed to the NS headquarters in Oslo. In this letter, Klüver embraced the foundation of a 'Nazi' organization in Norway and requested membership. His reason? 'For a long time, I have been interested in fascists and Nazis, through my personal friendship with the local Italian consul general, and it has always been my wish that also we in Norway can have a man who is interested in this ideal organization.'3 Thereafter, he referred to Vidkun Quisling, the founder and party leader of the NS, who would become a famous collaborator with Nazi Germany during the Second World War. Klüver's letter reveals the confusion caused by the foundation of the NS, both in Norway and abroad. What kind of party was the NS - Nazi or Fascist? Many contemporaries, including Klüver, did not even differentiate between the two.

Alternatively, was the NS an independent home grown party, as the party newspaper Nasjonal Samling insisted on in an article entitled 'NS is a national, Norwegian movement' in March $1934{ }^{4}{ }^{4}$ As is often the case in history, the answer lies somewhere in between. The NS was both a Norwegian phenomenon, originating in a specific domestic context, and part of a European phenomenon: a transnational right-wing movement based on anti-parliamentary and anti-socialist attitudes, inspired and influenced by Italian Fascism and German National Socialism. Previous research on the foundation of the NS and its early years, conducted almost exclusively by Norwegian historians, primarily focused on the internal, domestic development of the NS. ${ }^{5}$ Most historians have classified the NS as fascist, and some have analyzed the influence of both German National Socialism and Italian Fascism briefly. ${ }^{6}$ However, to date

1 This article is a shortened version of my master's thesis 'Norwegian Fascism in a Transnational Perspective: The Influence of German National Socialism and Italian Fascism on the Nasjonal Samling 1933-1936' (Humboldt-Universität zu Berlin and King's College London, 2017).

2 In this paper, the abbreviation NS means Nasjonal Samling, in contrast to the commonly used abbreviation in German research, where NS stands for Nationalsozialismus.

3 Letter from Johan Wilhelm Klüver to the NS party, 7 October 1933, RA, NS Partiarkiv, Del 1, Korrespondanse og saksarkiv, 1933. Politisk ledelse, Korrespondanse, utenriks. As every translation from Norwegian to English in the present paper, this is the author's own translation. The translations tend towards being literal, reflecting the language of the 1930s.

4 'NS er en nasjonal, norsk bevegelse,' Nasjonal Samling, 15 March 1934.

5 E.g. Hans Olaf Brevig and Ivo de Figueiredo, Den norske fascismen: Nasjonal Samling 1933-1940 (Oslo: Pax 2002).

6 E.g. Dag Olav Bruknapp, 'Ideene splitter partiet: Rasespørsmålets betydning i NS’s utvikling,' in Fra idé til dom: Noen trekk fra utviklingen av Nasjonal samling, ed. Stein Ugelvik Larsen and Rolf Danielsen (Bergen: Universitetsforlaget, 1976), 9-47; Øystein Sørensen, Hitler eller 
no one has explicitly used a transnational perspective in order to investigate fascism and the NS in interwar Norway. ${ }^{7}$

In this paper, I follow the transnational turn within the broader field of fascist studies by focusing on the NS as an example of a European-wide, transnational phenomenon. Accordingly, I will change the perspective from the domestic Norwegian to the international level, with a time frame of the years 1933 to 1936. On the domestic level, the party was founded in May 1933 and experienced a short rise followed by a period of demise, ending in catastrophic election results in 1936 with only $1.8 \%$ of the votes and a rapid decrease of party membership. ${ }^{8}$ From 1937 onwards, the NS was more a radical political sect rather than an influential party. On the international level, the period 1933 to 1936 , between the national socialist seizure of power in Germany and the establishment of the so-called Rome-Berlin axis, marked a period of rivalry between Mussolini's and Hitler's movements. Thus, 1933 and 1936 were deemed natural boundaries to my investigation period.

I use the ideological rivalry between Hitler's and Mussolini's regimes as an initial point of departure, asking: what impact did the the rivalry between Italian Fascism and German National Socialism have on the evolution and transformation of the NS? My main argument is that three transnational topics, that were also subject of the Italo-German rivalry, were decisive in the transformation of the NS: the role of corporatism; the NS's involvement in the international organization Comitati d'Azione per l'Universalità di Roma [CAUR; Action Committees for the Universality of Rome]; and the role of anti-Semitism. The German influence, in particular, led to a radicalization of the party due to the endorsement of anti-Semitic and racist attitudes. Nevertheless, the antagonism

Quisling: Ideologiske brytninger i Nasjonal Samling, 1940-1945 (Oslo: Cappelen, 1989); Øystein Sørensen, Solkors og Solidaritet: Høyreautoritcer samfunnstenkning i Norge ca. 1930-1945 (Oslo: Cappelen, 1991); Terje Emberland, Religion og rase: Nyhedenskap og nazisme i Norge 1933-1945 (Oslo: Humanist, 2003).

7 Works that focus on the entanglement between German and Norwegian right-wing movements are Nicola K. Karcher, 'Zwischen Nationalsozialismus und nordischer Gesinnung: Eine Studie zu den rechtsgerichteten Verbindungen norwegisch-deutscher Milieus in der Zwischenkriegszeit' (PhD diss., University of Oslo, 2012); and Hans-Dietrich Loock, Quisling, Rosenberg und Terboven: Zur Vorgeschichte und Geschichte der nationalsozialistischen Revolution in Norwegen (Stuttgart: Deutsche Verlags-Anstalt, 1970). The italian influence on Norway is mentionend in Salvatore Garau, Fascism and Ideology: Italy, Britain, and Norway (New York: Routledge, 2015); and Terje Emberland, Da fascismen kom til Norge: Den nasjonale legions vekst og fall, 1927-1928 (Oslo: Dreyers forlag, 2015).

8 Olav Njølstad, 'NS-medlemmene: Hvem var de?' norgeshistorie.no, accessed 4 May 2018, http://www.norgeshistorie.no/andre-verdenskrig/mennesker/1701-ns-medlemmene-hvemvar-de.html. 
between Mussolini's Fascism and Hitler's Nazism itself did not interest the NS, which perceived itself as independent national movement. In addition to this main argument, I will emphasize two findings. First, according to my research, Nazi Germany was the predominant role model for the NS during the investigation period. Second, this paper illustrates the usefulness of the transnational approach in the research on smaller fascist parties in general, providing new insights on the transformation of the NS.

My findings are primarily based on a systematic evaluation of the main NS party newspapers from the relevant years between 1933 and 1936. The three successive official NS newspapers - NS: Organ for Nasjonal Samling (1933); Nasjonal Samling (1934-1936), and Fritt Folk (1936-1945) - were controlled directly by the party leadership around Quisling and are, therefore, valuable sources in analizing the 'official' standpoint and ideology of the NS. However, one must emphasize that these sources tend to cover up tensions and disagreements within the party. Therefore, this method bears the risk of inadvertently accepting the propaganda of the fascists and painting an over-simplified picture, something to be mindful of when using such sources. In addition to the NS press, some primary sources have been used in order to analyze direct transnational contacts between the NS and foreign institutions.

\section{$1 \quad$ Fascist Studies and the Transnational Approach}

In recent years, fascist studies have been shaped by the so-called transnational turn. ${ }^{9}$ Promoters of the transnational approach understand fascism more as a fluid, entangled, and synchronic subject than as a generic and static phenomenon. They take the different national circumstances seriously, but include international aspects while focusing on the 'braided dynamic' of fascist movements. ${ }^{10}$ As Constantin Iordachi has argued, 'the evolution of fascist movements and regimes cannot be studied in isolation as they constantly influenced each other.'11 The transnational approach helps, therefore, to illuminate the international character of European fascism and to highlight the interaction of fascist parties and organizations on a transnational level. As David

See David D. Roberts, Fascist Interactions: Proposals for a New Approach to Fascism and Its Era, 1919-1945 (New York: Berghahn Books, 2016), 44-57.

10 Roberts, Fascist Interactions, 55.

11 Constantin Iordachi, 'Introduction: Fascism in Interwar East Central and Southeastern Europe: Toward a New Transnational Research Agenda,' East Central Europe 37 (2010): 195. 
D. Roberts has emphasized, 'a deeper focus on the web of interaction' marks the particularity of this new agenda. ${ }^{12}$

The transnationalism of fascist movements can be researched in two ways. First, one can investigate indirect connections between different movements by focusing on questions of transfer, translation, reception, and transmission of fascist ideas. ${ }^{13}$ Second, one can research direct agent-centered connections by analyzing organizations and networks that strengthened the impact of one fascist movement on the other. ${ }^{14}$ This category includes individuals called 'brokers', who established ties between fascist networks by mediating between different political systems and cultures. ${ }^{15}$ Transnational organizations are also predestined for this direct approach. An example in my own research is the CAUR, an organization founded by Italian Fascists in order to form a network for different national movements. In general, the category of indirect transnationalism with its focus on the reception in the press is more important to my research than the direct category, but both categories are interdependent and often only clearly distinguishable in theory.

Although Benito Mussolini, the world's first fascist leader, proclaimed that Italian Fascism was 'not merchandise for export' throughout the 1920s, many movements were founded in Europe that were directly inspired by developments in Italy ${ }^{16}$ These smaller movements were influenced by Fascism's opposition to

12 Roberts, Fascist Interactions, 44.

13 An example for this approach is an article by Salvatore Garau, who took the competition between Italy and Germany on the macro level in the early 1930s as starting point and researched on its impact on Oswald Mosley's party the British Union of Fascists (BUF) on a micro level. Salvatore Garau, 'The Internationalisation of Italian Fascism in the Face of German National Socialism, and its Impact on the British Union of Fascists,' Politics, Religion \& Ideology 15 (2014), 45-63.

14 One example for direct transnational research is Nicola Kristin Karcher's work on various right-wing German-Norwegian relations networks in the interwar period, such as the Nordische Geselleschaft and the Norske Nasjonalsocialister i Tyskland (Norwegian National Socialists in Germany). Cf. Karcher, 'Zwischen Nationalsozialismus und nordischer Gesinnung'.

15 An archetype of such a fascist broker is Giuseppe Renzetti, the contact man between Mussolini and Hitler, see Wolfgang Schieder, Faschistische Diktaturen: Studien zu Italien und Deutschland (Göttingen: Wallstein Verlag, 2008), 223-249.

16 Garau, 'The Internationalisation of Italian Fascism,' 46. 
international socialism and liberal parliamentarism, perceiving Fascism as an alternative 'third way' beyond liberalism and communism. At the end of the decade, Mussolini laid the groundwork for a change in his policy of Italian singularity by arguing that 'fascism is a purely Italian phenomenon in its historical expression, but its doctrinal postulates have a universal character.' ${ }^{17}$ This new openness to the international aspects of fascism was closely connected to the concept of Universalitá, which was 'explicitly related to the "myth of Rome" as a millenarian spiritual force inextricably linked to the physical space of the city.'18 In particular, a younger generation of Italian Fascists led by intellectuals such as Guiseppe Bottai and Asvero Gravelli perceived fascism as a universal, spiritual force and as the destiny for the whole world. Mussolini co-opted this idea and proclaimed in October 1930: 'Today I affirm that Fascism, as idea, doctrine, and realization, is universal: Italian in its particular institutions, and universal in spirit. ${ }^{19}$ Clearly, Mussolini saw Italian Fascism as the major leader of this new transnational power.

The year 1933 constituted a watershed, as German Nazism became the new star of the right-wing world. Suddenly, Italy's role as the senior fascist party was challenged, and striking disagreements between Nazi Germany and Fascist Italy came to the fore. The main bone of contention concerning foreign policy was Austria, where both sides supported competing fascist movements. ${ }^{20}$ Besides the political issues of foreign policy, there were also ideological disagreements between Italy and Germany. Important issues were the place of the Nordic-Aryan race and racism in general, and anti-Semitism in particular. ${ }^{21}$ These racist notions supposedly contradicted Italian Fascism and its policy of

17 Benito Mussolini, 'Preface,' in James Strachey Barnes, The Universal Aspects of Fascism (London: Williams \& Norgate, 1929), xxvii.

18 Aristotle Kallis, 'From CAUR to EUR: Italian Fascism, the 'Myth of Rome' and the Pursuit of International Primacy', Patterns of Prejudice 50 (2016): 362.

19 Cited in Michael Ledeen, Universal Fascism: The Theory and Practice of the Fascist International, 1928-1936 (New York: Howard Fertig, 1972), 63.

20 On the influence of the Italo-German rivalry on Austria, see: Karl Stuhlpfarrer, 'Austrofaschistische Außenpolitik: Ihre Rahmenbedingungen und ihre Auswirkungen,' in Austrofaschismus: Politik - Ökonomie - Kultur, 1933-1938, ed. Emmerich Tálos and Wolfgang Neugebauer (Wien: Lit Verlag, 2014), 322-337.

21 However, in recent research, this distinction has been questioned, emphasizing that racism in Italy inspired Nazi Germany. E.g.: Patrick Bernhard, 'Blueprints of Totalitarianism: How Racist Policies in Fascist Italy Inspired and Informed Nazi Germany', Fascism:Journal of Comparative Fascist Studies 6 (2017), 127-162, https://doi.org/10.1163/22116257-00602001. 
a corporative society based on solidarity. ${ }^{22}$ Nazi Germany on the other hand repudiated Italian claims of political leadership. ${ }^{23}$ Nonetheless, the antagonism between German and Italian Fascism did not prevent transnational transfers between the rivals. ${ }^{24}$

Mussolini's reaction to Hitler's seizure of power was to reinforce the internationalization of his own fascist ideology, in order to maintain the ideological primacy over kindred movements, ${ }^{25}$ and to combat the increasing international influence of German Nazism. ${ }^{26}$ To this end, the CAUR was established in $1933 .{ }^{27}$ The organization was an attempt to unite different allegedly 'fascist' national movements and to create a Fascist International, inspired by the common enemy, the Communist International. CAUR held several conferences and meetings in the following years without the presence of the NSDAP, which indicated the anti-German stance of the Italian organizers. However, the Italian aim to prevent further German influence on other kindred movements was not achieved in the long term. Even parties who participated in CAUR were increasingly attracted by the more radical and anti-Semitic style of German Nazism. ${ }^{28}$ The NSDAP remained unimpressed by the activities of CAUR and launched its own program to expand its international influence through several partly competing organizations.

The tense Italo-German relationship changed in late 1935 when, due to the invasion of Ethiopia, Italian foreign policy laid the groundwork for a closer relationship between Hitler and Mussolini. A further step leading to the rapprochement of the two rivals was the Spanish Civil War, in which both supported General Franco. This rapprochement led to the establishment of the Rome-Berlin axis in October 1936. The political rapprochement was attended by an ideological one. Pro-German notions within the ranks of Italian Fascists and the increasing influence of racist and anti-Semetic ideas and measures

22 The Italian Fascists opposed the idea of the superiority of the Nordic race but not the idea of racism as such; cf. Garau, 'The Internationalisation of Italian Fascism,' 53.

23 Arnd Bauerkämper, 'Transnational Fascism Transnational Fascism: Cross-Border Relations between Regimes and Movements in Europe, 1922-1939,' East Central Europe 37 (2010): 226 .

24 The best-known example was the German state-operated leisure organization Kraft durch Freude, that was directly modelled on the Italian organization Dopolavoro.

25 As argued by Kallis, 'From caur to EuR,' 367.

26 As argued by Bauerkämper, 'Transnational Fascism,' 226.

27 On the CAUR, see Marco Cuzzi, L'internazionale delle camicie nere : I caUR, Comitati d'azione per l'universalità di Roma, 1933-1939 (Milan: Mursia, 2005).

28 E.g. Anton Mussert's NSB and Marcel Bucard's Mouvement Franciste, see Kallis, 'From CAUR to EUR,' $371-372$. 
replaced idea of Universalitá. ${ }^{29}$ At the outbreak of the Second World War, German Nazism had changed from 'pupil to teacher', leading to an asymmetrical balance of power between the two former rivals. ${ }^{30}$ However, this rivalry had had a major impact on smaller European fascist movements, changing 'the wider dynamic in Europe and even beyond, adding new challenges, possibilities, and opportunities, and thereby altering the situation to which others had to respond.'31

\section{$3 \quad$ Nasjonal Samling, Neither Fascist nor National Socialist?}

Before the Nasjonal Samling was founded in 1933, several minor 'proto-fascist' movements had appeared in interwar Norway, being influenced either by Italian Fascism (such as the Fatherland League and the National Legion) or German Nazism (such as the National Socialist Workers' Party of Norway, NNSAP). The NS itself was officially established on Norway's constitution day, 17 May 1933, as a successor to a small anti-socialist organization called Nordic People's Uprising. Party founder and former Minister of Defense Vidkun Quisling was from the beginning in 1933 to the end in 1945 the most prominent person in the NS. He was proclaimed as unconditional Fører [leader] of the NS, the party adhering to the leadership principle that also characterized Hitler's and Mussolini's leadership. The first aim of the new party was the parliament (or: Storting) election on 16 October 1933, which turned out to be a fiasco. The political antagonist, the Arbeiderpartiet [Labor Party], won $40 \%$ of the electorate whereas the NS achieved only $2.2 \%(27,850$ votes $)$.

The party was from the beginning highly heterogeneous with conservative and more radical members, Christians and followers of neo-pagan religions, traditional Norwegian nationalists and members more influenced by Italian Fascism and German Nazism. Opinions differed massively, but there was a basic level of agreement about the party's ideology, predetermined by Quisling: anti-socialism, anti-parliamentarism and a vague desire for radical political change in Norway. ${ }^{32}$ One could differentiate between two antagonistic camps

29 Cf. Stanley Payne, A History of Fascism 1914-1945 (Madison: University of Wisconsin Press, 1996), 239-244.

30 Cf. Bauerkämper, 'Transnational Fascism,' $5^{8-59}$.

31 Roberts, Fascist interactions, 141.

32 Cf. Christhard Hoffmann, 'Die reine Lehre einer politischen Sekte: Antisemitismus in der norwegischen 'Nasjonal Samling,' in Vorurteil und Rassenhass: Antisemitismus in den faschistischen Bewegungen Europas, ed. Hermann Graml et al (Berlin: Metropol, 2001), 255. 
within the NS: the totalitarian, radical, anti-Semitic Nazi inspired strand, and the dominant authoritarian strand around Quisling and deputy chairman Johan B. Hjort rooted in nationalism and Christian values. However, many members were influenced by the German race researcher Hans F.K. Günther and his idea of a Nordischer Gedanke [Nordic idea], which insisted on the superiority of the Nordic-Aryan race. ${ }^{33}$ This belief, based on the völkisch-ideology, included strongly anti-Semitic attitudes. Günther's idea of racial hygiene as a means of defending the pure Nordic race from degeneration had become known (even though discussed controversially) in Norway through the race researchers Halfdan Bryn and Jon Alfred Mjøen.

In the first year of its existence, two ideas dominated the party's ideology. First, the NS explicitly had a sense of crisis and its solution through national rebirth. Both the yearning for national rebirth (what Roger Griffin terms palingenesis) and the sense of crisis are nowadays defined as fascist characteristics. ${ }^{34}$ According to the news coverage of the NS press, the spiritual crisis of the Norwegian nation had to be overcome by national unity under the leadership of Vidkun Quisling. Second, the NS refused to affiliate itself directly with Italian Fascism and German Nazism, even though a certain kinship was admitted. It was probably no coincidence that the Nasjonal Samling was established a few months after Hitler's seizure of power in Germany, even though domestic Norwegian dynamics had led to its formation. Tellingly, the abbreviation NS, in Germany referring to Nationalsozialismus, was suspicious. Large parts of the Norwegian press therefore assumed that Quisling's movement was fascist or National Socialistic. The labor newspaper Arbeiderbladet claimed that Quisling had established 'Hitler's Norwegian branch'. ${ }^{35}$

However, Quisling and his party colleagues neglected both 'fascism' and 'Nazism' as a term of self-description, as Quisling made clear in a public speech in August 1933: 'We are not trying to adapt any foreign doctrine here in this country. ... We seek to solve the issues based on the Nordic conditions and to accommodate things to Norwegian purposes. We neither want Fascism nor

33 On Günther and the Nordic idea, see Terje Emberland and Matthew Kott, Himmlers Norge: Nordmenn i det storgermanske prosjekt (Oslo: Aschehoug, 2012), 56-65.

34 The idea of national rebirth was essential to the fascist minimum defined by Roger Griffin as the palingenetic form of populist ultra-nationalism. Roger Griffin, The Nature of Fascism (London: Pinter, 1991), 26. Robert Paxton argued that passionate nationalism was at the bottom of every fascist movement, followed by 'a sense of overwhelming crisis beyond the reach of any traditional solutions.' Robert O. Paxton, The Anatomy of Fascism (New York, Knopf Doubleday, 2004), 41.

35 Cf. Leading article, Arbeiderbladet, 2 September 1933. 
National Socialism. ${ }^{36}$ The NS party journal mentioned Italy and Germany occasionally, but an article called 'The ideological base of our movement' raised the question of how Fascism and Nazism were related to the party. ${ }^{37}$ The article emphasized the NS's Norwegian spiritual and national 'egenart' [idiosyncrasy, distinctiveness], which for party spokesman Eyvind Mehle constituted the reason for the ideological independence from other, kindred movements. 'Therefore, it is clear that we can never rely on Fascism or National Socialism, which emerged from Italian and German national conditions, but we can learn practical lessons from the struggles of these movements. ${ }^{38}$ Mehle's statement sums up the party's general position. The NS refused to label itself as Fascist or National Socialist but admitted a certain kinship to the movements in Italy and Germany. The explanation for this is simple. The term 'Nazi' was used pejoratively, to discredit political opponents, especially in a country with a liberal tradition such as Norway. However, other movements in similar countries used the self-descriptions Nazi and fascist, such as Frits Clausen's National Socialist Workers' Party of Denmark (DNSAP) and the Swedish National Socialist Party (SNSP), both labelling themselves as 'Nazi'. In Britain there was the British Union of Fascists and the Imperial Fascist League. In Norway, the unsuccessful cases of the National Legion (fascist) and the NNSAP (Nazi) had shown that there was nothing to gain from calling oneself fascist or Nazi, an experience that clearly affected the NS.

In addition, the party had, at least in the way it presented itself in its own news coverage, a self-conception of being an independent, national phenomenon. Quisling supported this idea of national independence, initially being neither pro-Italian nor pro-German, but pro-British. He dreamt of combining Italian Fascism and German National Socialism into his own political synthesis, expressed by the ideology of the NS. ${ }^{39}$ The focus on Norwegian independence from other European fascist movements was illustrated by the party's emphasis on Norwegian (mostly medieval) history and traditions. This was represented by the NS party symbol, the Olavkorset, a sun cross based on the national saint Olaf. The obvious alternative would have been the swastika, which the DNSAP in Denmark and the SNSP in Sweden had gladly copied from the German role model. A similar example was the use of the Old Norse greeting 'Heil og sæl' [healthy and happy] as the NS's form of salutation, including

\footnotetext{
36 Cited in Hans Fredrik Dahl, Vidkun Quisling: En fører blir til (Oslo: Aschehoug, 1991), 351.

37 'Vår bevegelses ideologiske grunnlag,' NS - Organ for Nasjonal Samling, 27 September 1933 .

38 Ibid.

39 Cf. Dahl, Vidkun Quisling, 376.
} 
the raising of the right hand. ${ }^{40}$ The salutation remained Norwegian, but the style was clearly inspired by the Fascist Roman salute and the Nazi salutation 'Heil Hitler'. To sum up, the NS refrained from calling itself fascist or national socialist and from using direct Nazi or fascist symbols, while still being influenced by the style of mass politics and its rituals, practiced by both Italian Fascism and German Nazism.

\section{Italian Corporatism and German Advocacy in 1934}

1934 was the first year that the NS could boast professional propaganda and press activity. The main party newspaper was renamed Nasjonal Samling and appeared from 15 March 1934 on a weekly basis, filled with articles about domestic and foreign policy, culture, and party events. In addition, the first and only official party manifesto was published..$^{41}$ Neither Italy nor Germany were mentioned explicitly in the party manifesto, but both influenced the program, with Italy playing a predominant role. As Salvatore Garau argued, 'Italy's corporate state, with its unions subject to a strong state, provided inspiration for the NS as it drafted its own brand of corporatism. ${ }^{42}$ Corporative ideas presented in several articles of the manifesto and the party press illustrated that the NS, at least economically, took Italian Fascism as a role model in $1934 .{ }^{43}$ Like many other right-wing movements, the NS was clearly inspired by the 'corporist moment' of the interwar period. ${ }^{44}$ Thereafter, it adapted the idea of a corporative chamber, which had been established in Italy in 1928, into the Norwegian context - renamed under the Old Norse name Riksting in July $1934 .{ }^{45}$ This Riksting as a voluntary corporative organization was a self-experiment on its own and therefore more than a mere imitation from Italy, especially since

40 Cf. Brevig and de Figueiredo, Den norske fascismen, 43.

41 'Nasjonal Samlings Program,' Nasjonal Samling, 15 March 1934.

42 Garau, Fascism and Ideology, 216. On corporatism in general and its role for fascist movements, see: Antonio Costa Pinto, ed., Corporatism and Fascism: The first Corporatist Wave in Europe (New York: Routledge, 2017).

43 Especially Article 2 of the manifesto stated that cultural and business life had to be gathered in so-called laug (guilds) of occupational groups, which should be organized in a Riksting (realm thing, the Old Norse name for the governing assembly of northern Germanic societies).

44 Cf. Aristotle Kallis, 'Conclusion: The "Corporist Moment" in inter-war Europe,' in Corporatism and Fascism: The First Corporatist Wave in Europe, ed. Antonio Costa Pinto (New York: Routledge, 2017), 292-298.

45 'Norges faglige riksting,' Nasjonal Samling, 26 July 1934. 
corporatism had already been discussed by the Fatherland League in the Norwegian context in the late $1920 .^{46}$ Nonetheless, the ideological transfer from the original version in Italy to the NS in Norway was quite apparent.

However, compared to Italy, Germany was without doubt more present in the NS press from 1934 onwards. Not only was the country geographically and historically closer to Norway, the way Hitler's regime rapidly changed the country after only one year in office was of much more interest than the wellestablished senior fascist power Italy. The NS strategy in part allowed affiliation with both Italian Fascism and German Nazism, but no direct labelling of one of those. Fører Quisling emphasized in an article in March 1934 that the NS 'should not be considered a copy of German National Socialism, even though the movement has the same spiritual foundation.47 Quisling's most significant statement was even printed in German: 'Wir sind ... kein Ableger von Deutschland. ${ }^{48}$ The article ended with a remarkable statement that emphasized the fluid and transnational character of the NS: 'The aim of the Nasjonal Samling is that we not only get impulses from outside but that we also give in return good and fruitful impulses. 49

Nonetheless, during 1934 it became apparent that the Nasjonal Samling saw itself as the only journal in Norway that defended developments in Nazi Germany, while the rest of the Norwegian press frequently criticized these events. The journal attacked both journalists and politicians for criticizing Germany and used famous spokesmen such as the winner of the Nobel Prize in Literature Knut Hamsun in order to defend Nazism..$^{50}$ In a few cases, the NS press revealed its true admiration for Hitler and Nazi Germany, in particular in the aftermath of the Night of the Long Knives (in Nazi Germany referred to as the Röhm-Putsch). The purge aimed at the disempowerment of the Sturmabteilung (SA) and the extrajudicial execution of its leader Ernst Röhm. ${ }^{51}$ The SS and the Gestapo executed at least eighty five people (with some estimates as high as 150-200) during the events. The NS party leadership decided to defend

46 Cf. Sørensen, Solkors og Solidaritet, 48-64.

47 'NS er en nasjonal, norsk bevegelse,' Nasjonal Samling, 15 March 1934.

48 Ibid.

49 Ibid.

5o E.g. Knut Hamsun, 'Tyskland og vi,' Nasjonal Samling, 12 April 1934.

51 Interestingly, the NS established an own paramilitary wing in 1934 similar to the German Sturmabteilung. It was named Spesialavdeling [Special Department] and was at first, what a coincidence, abbreviated SA. However, maybe as a consequence of the disempowerment of the original German SA, or as an act of underlining the Norwegian distinctiveness, the name was in the same year changed to Hirden, a Nordic medieval name for the bodyguards of the King. See: Brevig and de Figueiredo, Den norske fascismen, 45. 
this event, which was harshly criticized even by Italian Fascists, ${ }^{52}$ by following the official German Nazi propaganda line that the purge was necessary to prevent an alleged coup d'état against Hitler. Two large articles in the journal Nasjonal Samling argued that the purge was an important step for the development of National Socialism and that the enthusiasm for Hitler was now stronger than ever before. ${ }^{53}$

Italian Fascism was, in contrast, of lesser importance in the news coverage. However, the NS press observed and supported Mussolini's course of internationalization and his aim of spreading fascist ideas in Europe in several articles. Fascism was often interpreted less as an Italian phenomenon, but rather as a term for all anti-capitalist and anti-communist movements, being 'the first wave of the national storm flood rushing over Europe. ${ }^{54}$ The NS clearly located itself within the community of fascism as a European phenomenon of anti-liberalism and anti-communism. Therefore, the NS press highlighted positive aspects of other fascist movements around Europe including the two role models Italy and Germany and emphasized the common ideological background as reaction to the European spiritual, social and economic crisis.

\section{CAUR, Quisling and the New Transnational Order}

Through an Italian diplomat in Norway, the NS corporative party manifesto came into the hands of Eugenio Coselschi, the president of the abovementioned CAUR. Coselschi decided to invite Quisling to the first CAUR conference on 16-17 December 1934 in Montreux as the representative of Norway. Quisling agreed to attend the conference, as he stated in a letter to Coselschi, 'to learn from Italian Fascism'. ${ }^{55}$ Along with Quisling, for whom this was the first trip abroad as party leader, delegates from eleven other countries participated. Even though no delegate of the NSDAP was present at the conference, the rivalry between Italian Fascism and German Nazism played a central role, especially concerning ideological questions. ${ }^{56}$ Quisling himself

\footnotetext{
52 Payne, A History of Fascism 1914-1945, 232.

53 'Nasjonalsosialismens vei fra erobrende til byggende bevegelse,' Nasjonal Samling, 5 July 1934; and 'NS propagandasjef forteller om to spennende uker i Tyskland,' Nasjonal Samling, 19 July 1934.

54 'Fascisme over Europa,' Nasjonal Samling, 24 May 1934.

55 Cited in Dahl, Vidkun Quisling, 357.

56 Kallis, 'From caUr to EUR,' 371.
} 
spoke, proclaiming that neither Italy nor Germany should dominate such an international organization. Quisling cited the Nordic idea and the superiority of the Nordic race, thus disputing the primacy of Rome. ${ }^{57}$ Despite all disagreements, a mutual resolution based on corporative ideas was formulated. Anti-Semitism, still moderately formulated, became part of this resolution, prompted by the Dane Frits Clausen and the Romanian Iron Guard's delegate Ion Mota. ${ }^{58}$ The delegates also agreed to form a permanent executive committee. Together with other European fascist leaders such as the French Marcel Bucard and the Irish Eoin O'Duffy, Quisling was elected a member of the committee. In the end, Quisling's speech, protesting against the influence of the two major powers Italy and Germany, emphasized the importance of smaller movements, and underlined what the Nasjonal Samling had proclaimed since 1933. The NS was an independent, Norwegian movement, not interested in merely copying from the two role models. However, Quisling's participation in the conference and his joining CAUR's executive committee, eroded the impression that NS was clearly independent from Mussolini's version of fascism. This provoked objections from within both the Christian-nationalist and the national socialist strands of Quisling's own party. ${ }^{59}$

With regard to the NS's involvement in CAUR historians such as Arnd Bauerkämper and Salvatore Garau have interpreted CAUR as an instrument of Italian power, used to retain ideological supremacy over German Nazism. ${ }^{60}$ Contemporaneously, however, NS interpreted CAUR as a transnational expression of equal national movements in the common battle against materialist

57 'Il ne faut pas oublier qu'une partie de l'Europe est restée en dehors de l'influence romaine.' Vidkun Quisling's speech, in: Comités d'Action pour l'Universalité de Rome, ed., Réunion de Montreux 16-17 décembre 1934-XIII (Rome, 1935), 60.

$5^{8}$ On Mota and the CAUR, see: Raul Cârstocea, 'Native Fascists, Transnational Anti-Semites: The International Activity of Legionary Leader Ion I. Moţa,' in Fascism without Borders: Transnational Connections and Cooperation between Movements and Regimes in Europe from 1918 to 1945, ed. Arnd Bauerkämper and Grzegorz Rossoliński-Liebe (Oxford: Berghahn, 2017), 228-231.

59 National socialists within the NS clearly disliked this direct affiliation with Italy, which only confirmed the impression of a policy influenced by Italian Fascism, indicated by the corporative program and the lack of anti-Semitism and racism. Consequently, in the end of 1934 leading Norwegian National Socialists such as Hans S. Jacobsen and Walter Fürst left the party disappointed by Quisling's moderate policy. Instead, they founded their own journal Ragnarok. See the chapter 'Striden om Montreux,' in: Dahl, Vidkun Quisling, 364-369.

6o See Arnd Bauerkämper, Der Faschismus in Europa 1918-1945 (Stuttgart: Reclam, 2006), 171; Garau, 'The Internationalisation of Italian Fascism', 51. 
forces. In an interview about the Montreux conference, Quisling argued that there was a new, universal philosophy and order, with Nazism as the German, Fascism as the Italian, and NS as the Norwegian version. ${ }^{61}$ Each country had to find its own solutions adjusted to its own conditions, but what Quisling had experienced at the conference was that all the national movements had analogous answers to the significant questions. Optimistically, Quisling stated that 'it is only a question of time when this new order will break through to victory on our entire continent.' ${ }^{62}$ Quisling focused only on the broad, philosophical aspects of the conference, thereby presenting CAUR as a transnational expression of this new order in contrast to the old systems of liberalism and communism. An article in April 1935 about CAUR's second meeting in Amsterdam described the organization as 'the path to national and international peace and understanding. 63 According to Quisling, 'the main intention of the conference was to create personal contacts between the various national movements in Europe and elsewhere in the world, in order to contribute as far as possible to the promotion of peace and mutual understanding between the peoples' ${ }^{64}$ States controlled by liberalism and Marxism were presented as warmongers, while the third group, defined by Quisling as 'the new national social corporate order, based on an organically built corporative society with strong and stable governance', was only interested in peace. ${ }^{65}$ In September 1935, another large article covered a second conference in Montreux. ${ }^{66}$ In this article, CAUR was fulsomely praised for being an organization with a million people in seventeen states all over the world. The article reported on two resolutions by the executive committee of CAUR, the first being a protest against possible sanctions by the League of Nations against Italy due to the forthcoming war against Ethiopia. According to the second resolution, a new world league had to be built on the ruins of the failing League of Nations. 'Instead of the old diplomatic hypocritical tactical methods, we must create a direct and honest cooperation between all the young and healthy national movements, in order to achieve a general spiritual renewal and political revival in the world. ${ }^{67}$

Thus, in the NS's perspective, CAUR represented a new national order appearing all around Europe, enforced by movements such as Italian Fascism,

\footnotetext{
61 'Europa under utformning i nasjonale folkesamfund,' Nasjonal Samling, 3 January 1935.

62 Ibid.

63 'Veien til nasjonal og internasjonal Fred og Forståelse,' Nasjonal Samling, 11 April 1935.

64 Ibid.

65 Ibid.

66 'Et nytt Verdensforbund,' Nasjonal Samling, 19 September 1935.

67 Ibid.
} 
German Nazism (ignoring the fact that the NSDAP did not participate in the CAUR) and the NS in Norway. This new order was represented as antagonistic to the united front between the allegedly warmongering forces of liberalism and Marxism. In addition, the peaceful character of the CAUR was highlighted. Notably, the name of the organization was not mentioned explicitly in any of these articles, perhaps due to Quisling's objection to the idea of the Universalità di Roma (presented in the organization's name).

Until September 1935, the organization had been projected as a project for peace and mutual understanding. Henceforth, the proposition that the CAUR should replace the outdated League of Nations, became a very problematic view, because Italy appeared now as the aggressor in the Italo-Ethiopian war (1935-1936). Therefore, the NS press did not advocate the Italian case as strongly as it had done a year beforehand when devoting so much time to Germany and the Röhm-Putsch. This was despite the fact that the Italian envoy in Norway, Marcello Roddolo, had distributed material to the Nasjonal Samling and other Norwegian newspapers about the Ethiopian war and had even ordered a payment of 1,000 Norwegian Crowns to the NS, hoping for a positive war coverage. ${ }^{68}$ Instead, the Italo-Ethiopian war was used by the NS press as an argument against the League of Nations and its policy of sanctions against Italy ${ }^{69}$ However, Quisling left the CAUR due to the war, the last contact being in February 1936, and also because many NS members disapproved of Quisling's affiliation to such an international organization.

Transnational Anti-Semitism in 1935

In 1935, the Nasjonal Samling followed the same strategies in writing about German Nazism as earlier, by criticizing the Norwegian press for its unfair treatment of Germany, by letting others speak in favor of it, and by praising Germany directly. However, the coverage explicitly left out one of the essential events of the year: the anti-Semitic Nuremberg Laws presented in the German Reichstag on 15 September 1935. These were the 'Law for the Protection of German Blood and German Honor', prohibiting marriages and extramarital intercourse between Jews and Germans, and the 'Reich Citizenship Law', declaring that only those of German or related blood were eligible to be Reich

\footnotetext{
68 Dahl, Vidkun Quisling, 372.

69 The Italo-Ethiopian war lasted from 3 October 1935 to 5 May 1936. The League of Nation acted immediately and imposed economic and financial sanctions upon Italy.
} 
citizens. ${ }^{70}$ Both laws institutionalized National Socialist anti-Semitic and racist attitudes in Germany.

In Norway, anti-Semitism had been present long before the establishment of the Nuremberg Laws. The Norwegian constitution from 1814 had explicitly forbidden the residence of Jews. This paragraph was later abolished, but an anti-Semitic sentiment in the Norwegian society remained, especially flourishing in the interwar period..$^{71}$ The low proportion of Jews (0.05\%, ca. 1,350 people) within Norway's otherwise largely homogeneous population did not prevent anti-Semitism. Since the foundation of the NS, some members had been strongly anti-Semitic, especially the totalitarian strand of the party. ${ }^{72}$ Ideas of the superiority of the Nordic-Aryan race had been established in the NS through race researchers such as Günther, Bryn and Mjøen. ${ }^{73}$ Nonetheless, a moderate, subliminal form of cultural anti-Semitism initially prevailed in the NS press and its self-presentation. ${ }^{74}$ The NS party manifesto from 1934 did not mention Jews and until 1935, Quisling never attracted attention with antiSemitic expressions.

However, from mid-July 1935 on, anti-Semitic and racist attitudes in the NS press became more obvious. This was connected to Halldis Neegård Østbye, who became a leading figure in the production of anti-Semitic NS propaganda in the following years. ${ }^{75}$ Østbye initiated the anti-Semitic campaign in July 1935 , by stating that the claim in the liberal press all over the world, that the famous anti-Semitic Protocols of the Elders of Zion were a falsification, was wrong. ${ }^{76}$ According to Østbye, no one else than 'the international Jewish-finance and the international Jewish-Marxism' itself had convinced the press to spread this

70 About the Nuremberg Laws, see Peter Longerich, Holocaust: The Nazi Persecution and Murder of the Jews (Oxford: Oxford University Press, 2010), 57-61.

71 About anti-Semitism in Norway, see: Einhart Lorenz, 'Antisemitismus in Norwegen Nordische Aspekte eines gesamteuropäischen Phänomens,' in Der skandinavische Weg in die Moderne: Beiträge zur Geschichte Norwegens und Schwedens vom Spätmittelalter bis ins 20. Jahrhundert, ed. Peter Brandt et al (Berlin: BwV Verlag, 2016), 125-146.

72 About anti-Semitism within the NS, see Hoffmann, 'Die reine Lehre einer politischen Sekte.'

73 Bruknapp, 'Ideene splitter partiet,' 11.

74 Nonetheless, anti-Semitic attitudes had been present in the NS press, for example in the campaign against the German-Jewish doctor and sexologist Max Hodann, who's books had been published in Norway.

75 Climax of Østbye's anti-Semitic propaganda was her book The Jewish question and its solution, published in 1938. Østbye, Halldis Neegård, Jødeproblemet - og dets løsning (Oslo: I. Sverd, 1938).

76 'Makten over verdenspressen,' Nasjonal Samling, 11 July 1935. 
alleged lie. ${ }^{77}$ The NS press used the idea of a secret alliance between liberalism and Marxism, often presented as antagonism to fascism, frequently. The idea that the international Jewry stood behind the alliance, uniting liberalism and Marxism was new. Quisling adopted this idea in his strongly anti-Semitic speech in Oslo on 24 September 1935, only a few days after the Nuremberg Laws had been passed in Germany. For the first time, the party leader openly expressed anti-Semitism in public. ${ }^{78}$ Quisling claimed in his speech that $90 \%$ of the forces behind Marxism where 'whole or half Jews. ${ }^{79}$ This rhetoric was clearly inspired by the terminology of the Nuremberg Laws. A strongly racist article, defining the Jewish people as a foreign race that could not be assimilated, even if it changed its religion, strengthened the new anti-Semitic line of attack. 'Such a foreign element must sooner or later create a cause for conflict in any organized society', even in Norway with its minimal number of Jews. ${ }^{80}$ The article emphasized Quisling's suspicion about the aim of a 'Jewish Soviet World Republic'.81 The consequences were real for Norway since the Norwegian press and politicians were under the influence of the Jews. Norway for the Norwegians', one of the subtitles of the article, became a popular NS propaganda slogan..$^{2}$

In autumn 1935, several articles repeated the anti-Semitic statements in various modifications, often connected to the Italo-Ethiopian war and the League of Nations. The League was interpreted as a Jewish instrument in the pursuit of a 'Jewish World Republic'.83 The conspiratorial idea of liberalism and Marxism both being united in one front that was secretly controlled by 'International Jewry' brought the NS to a new level of Nazi-style propaganda. Anti-Semitic and racist attitudes now had their breakthrough, paradoxically after a significant number of members from the totalitarian strand had left the party exactly because of the lack of these attitudes. One outstanding example of this new level of anti-Semetism was an article about the Soviet Union, which was allegedly chasing Ethiopia's natural resources. ${ }^{84}$ The article brimmed with anti-Semitic conspiracy theories about 'International Jewry' being behind the whole conflict, claiming that they planned to make Ethiopia dependent upon

77 Ibid.

78 Bruknapp, 'Ideene splitter partiet,' 27.

79 Hans Fredrik Dahl, Quisling - en norsk tragedie (Oslo: Aschehoug, 2012), 185.

80 'Jødespørsmålet,' Nasjonal Samling, 26 September 1935.

81 Ibid.

82 Ibid. Originally, the slogan was used in the context of Norwegian independence in 1905.

83 'Fred en tvingende nødvendighet,' Nasjonal Samling, 26 September 1935.

84 'Sovjekt på jakt efter Etiopias naturrikdommer', Nasjonal Samling, 24 October 1935. 
'Jewish High Finance'. The aim was to create a Jewish World Republic, 'where organic living life is levelled to the ground, where rootless Judaism, which is unable to create a culture of its own, can grow and scrounge, and where the 'chosen people' can exercise its world domination.'85 Other NS newspapers directed their venom towards Gypsies, blacks and other races, but the main newspaper Nasjonal Samling remained focused on anti-Semitism. ${ }^{86}$

The attacks against Jews continued throughout the end of the year, arousing enthusiasm within the national socialist ranks in and outside the NS as well as opposition from the more Christian and authoritarian strand of the party. Some of the moderate members left the party disappointed by the new radical course, including for example the priest Martin Tveter who had been one of the figureheads of the Christian strand of the NS. ${ }^{87}$ Quisling himself declared at the end of the year at a party leader meeting that anti-Semitism was now officially part of the NS ideology. ${ }^{88} \mathrm{He}$ wanted agitation against Jews in general, but not racial hatred against individual Jews. ${ }^{89}$ Therefore, one has to emphasize that the NS leadership refrained from requesting attacks on individual Jews, for example in form of boycotts. Anti-Semitic propaganda remained present in the NS press in 1936, when numerous articles about the topic were published. ${ }^{90}$ In conclusion, news coverage in autumn 1935 marked the NS's transformation from a moderate to a radical form of anti-Semitism.

The significant question is: why this sudden change from moderate, subliminal anti-Semitism to aggressive, conspiratorial racial-based anti-Semitism in the second part of 1935? Historians have given different explanations so far. Dag Olav Bruknapp argued on the one hand, that the participation of the $A r$ beiderpartiet in the government and its acceptance of democratic rules led to the loss of the main argument against the Labor party, the former arch-enemy of the NS. ${ }^{91}$ The Jews were the natural replacement. ${ }^{92}$ On the other hand, there

85 Ibid.

86 Cf. Bruknapp, 'Ideene splitter partiet,' 24.

87 Ibid., 32.

88 About Quisling's view on the Jews see also his speech given to NS party members in 1935, printed in Hans Fredrik Dahl, Quislings nettverk (Oslo: Aschehoug, 2015), 185-186.

89 Cf. Dahl, Vidkun Quisling, 388.

9o See for example an article about the synthesis of anti-Semitism and Christianity: 'Nasjonal Samling og Jødene: Kan en kristen være antisemitt?' Fritt Folk, 11 May 1936.

In March 1935, the liberal Mowinckel government was replaced due to the so-called Kriseforliket, a crisis settlement between the labor party and the farmer's party. This settlement led to a shift of governmental power with Johan Nygaardsvold from the labor party becoming new Prime Minister.

Cf. Bruknapp, 'Ideene splitter partiet,' 27. 
was also a percieved 'threat' in Norway, because five thousand Jewish refugees from Germany had asked for entry permits in 1935, leading to a debate in the Norwegian public. ${ }^{93}$ In contrast, Christhard Hoffmann has argued that the radicalization of the NS was a result of the huge losses in two major elections, the parliamentary election 1933 and the municipal elections 1934. As a consequence, the internal party identity could only be stabilized by ideological radicalization. The solution was radical anti-Semitism, which differentiated the NS from other Norwegian parties and presented a scapegoat for the bad election results. ${ }^{94} \mathrm{~A}$ third view has been presented by Salvatore Garau, who interpreted increasing anti-Semitism within his model of authoritarian versus totalitarian parts of the NS: increasing anti-Semitism was an expression of the totalitarian (National Socialist) strand within the party outrivaling the authoritarian, Christian strand. ${ }^{95}$ This argument seems weak, since leading figures of the 'totalitarian strand', such as Hans S. Jacobsen and Walter Fürst, had left the party a year earlier. However, all these internal explanations are in part correct. Nonetheless, I argue that both the indirect and the direct transnational level as mentioned above is significant to understanding the sudden change. ${ }^{96}$

On the indirect transnational level, the increasing anti-Semitism in the NS in 1935 correlated with the internal German developments, even before the Nuremberg Laws were imposed. The Nuremberg Laws were not established unexpectedly, but ideologically prepared over a long period. After the first boycotts in Germany in 1933, increasing anti-Jewish violence in February 1935 brought the topic to the fore. The implementation of laws against 'mixed marriages' was announced by Reich Minister of the Interior Wilhelm Frick on 25 July, months before the party rally in Nuremberg. It was therefore known that anti-Semitism would be institutionalized in the German state, and the first anti-Jewish attacks in the Nasjonal Samling conducted by Østbye suited this trend. Subsequently, the Nuremberg Laws itself had a major impact on the level of imitation and transfer: most anti-Semetic articles in the NS appeared after the laws were presented in Germany, and Quisling himself used terminologies inspired by the Nuremberg Laws such as 'half Jew' in his agitation. This indicates, that the increasing anti-Semitism in the NS was at least in part influenced by the actions of Hitler's regime. However, this is still far from being evidence of the direct transfer from German to Norwegian anti-Semitism.

\footnotetext{
93 Ibid., 28.

94 Hoffmann, 'Die reine Lehre einer politischen Sekte,' 259.

95 Garau, Fascism and Ideology, 248.

96 Bruknapp mentioned the German influence, bud dismissed it as factor due to Quisling's various statements on the independence of the NS from Nazi Germany. Bruknapp, 'Ideene splitter partiet,' 29 .
} 
Even though there were several contacts between Norwegian fascists and German National Socialists, the NS and the NSDAP established no permanent contact in the years 1933-1936. ${ }^{97}$ However, in the direct aftermath of the Nuremberg Laws in September 1935, Quisling was suddenly contacted by Paul Wurm, editor of the foreign section of Der Stürmer. ${ }^{98}$ Wurm was the leader of the Antijüdische Weltliga, an offshoot of the journal. ${ }^{99}$ Its aim was to gather international anti-Jewish material and to extend the reach of Der Sturmer's propaganda to a foreign audience. Accordingly, Wurm and the Antijüdische Weltliga used personal contacts and networks. In autumn 1935, Quisling received not only an invitation to the annual NSDAP Nuremberg rally, but also a special issue of Der Stürmer with an overview of the alleged Jewish infiltration and influence in Western European countries. ${ }^{100}$ Quisling replied to Wurm that he regretfully could not join the rally, but that he had read the received material with particular interest. ${ }^{101}$ Subsequently, Quisling admitted in clumsy German language that Nazism had influenced the NS's thoughts on Jews:

Unsere Aufmerksamkeit der Judenfrage gegenüber ist stets gescharft [sic] worden. Obschon die Juden in Norwegen zahlmässig keine hervorragende Position haben, wird es täglich stärker eingesehen - besonders nach der Entschleierung des occulten Judentums durch die nationalsozialistische Erhebung Deutschlands - dass der Einfluss der Judenmacht und Judenmoral einen entscheidenden en Greif [sic] in der Weltentwicklung sowie für die Zukunft unseres Heimatlandes zustrebt. ${ }^{102}$

The first contact between the NSDAP and the NS had been established through the SS official Max Pferdekämpfer in late 1933. In summer 1934, the leader of the Nordische Gesellschaft Thilo von Trotha was present at a NS party convention and had several meetings with Quisling. They met again in Berlin in December 1934, when von Trotha introduced Quisling to Alfred Rosenberg. Dahl, Vidkun Quisling, 353-360.

98 Dahl, Quisling - en norsk tragedie, 183.

99 About Paul Wurm and the Antijüdische Weltliga, see Magnus Brechtken, 'Madagaskar für die Juden': Antisemitische Idee und politische Praxis 1885-1945 (München: Oldenbourg Wissenschaftsverlag, 2009), 72-74.

100 Dahl, Vidkun Quisling, 379.

101 Letter from Vidkun Quisling to Paul Wurm, 21 September 1935, RA, NS Partiarkiv, Del 1, Korrespondanse og saksarkiv, 1935. Politisk ledelse. Tyskland.

102 Letter from Vidkun Quisling to Paul Wurm, 21 September 1935. Translation: Our attention to the Jewish question has always been sharpened. Although the Jews in Norway do not have an overwhelming position in terms of numbers, it is more strongly recognized every day - especially after the unveiling of occult Judaism by the national socialist uprising of Germany - that the influence of the Jewish power and Jewish morality is aimed at a decisive intervention in the world's development as well as for the future of our home country. 
The letter ended with a request for Wurm to send more editions of the special issue of Der Stürmer to the NS party organization, so that the journal could be used for 'Aufklärungszwecke' [reconnaissance purposes]. ${ }^{103}$ The letter was sent on 21 September, three days before Quisling gave his first strongly antiSemitic speech. The exchange between Quisling and Wurm is a perfect example for the direct level of transnational influence, leading to the conclusion that Quisling was both inspired and prompted by Nazi Germany (represented by Paul Wurm) to intensify anti-Semitic propaganda in Norway.

NS press activity in 1936 revealed without doubt, whom the Nasjonal Samling preferred: Germany was the role model in many domestic and foreign policy aspects, admired as a weapon against the Soviet Union, as a peace loving nation, as a country of law and order, and as an economically successful society. Italy on the other hand, although still present, had clearly a subordinate position to Germany. As in the years before, Italy was largely referred to only in the context of foreign relations. ${ }^{104}$ Domestic developments played hardly any role in the NS press, in stark contrast to the coverage of Germany. Not being a Nordic-Aryan nation, Italy lacked the certain 'racial' characteristic to play a more important role for the NS. This was exemplified by the exclusion of Italy from Quisling's plan for a Nordic World Federation, an association that included the Scandinavian countries, Great Britain, Germany, the Netherlands and other 'Nordic countries.' ${ }^{105}$ Nevertheless, the prospect of a rapprochement between Italy and Germany constituted a sign of hope for the NS during 1936, and was interpreted as supporting the current battle of the national movements against their numerous enemies. ${ }^{106}$ However, the hope that the success of the national movements in Italy and Germany would lead to increasing popularity of the NS in Norway turned out to be an illusion, as illustrated in the heavy loss in the Storting election with only $1.8 \%$ of the votes. In addition, 1936 brought a dramatic decrease of party members from 8,542 to less than $2,700 .{ }^{107}$ Thus, the

\footnotetext{
103 Ibid.

104 One exception was an article about the foundation of the Italian city Aprilia, which was praised as an Italian conquest. 'En italiensk erobring i Italia,' Fritt Folk, 23 June 1936.

105 'Et nordisk verdenssamband,' Fritt Folk, 29 June 1936.

106 E.g. 'SNAKK i Genf og Montreux - HANDLING i Berlin, Wien og Rom,' Fritt Folk, 13 July 1936.

107 Olav Njølstad, 'NS-medlemmene: Hvem var de?'
} 
increasing endorsement of German Nazism fuelled the transformation of the NS from 'a party to a radical political sect'. ${ }^{108}$

\section{Conclusion}

Based on systematic research on the Italo-German reception in the NS press in the period 1933-1936, I argue that certain transnational issues that were subject of the Italo-German rivalry such as corporatism, the involvement in the international organization CAUR and the role of anti-Semitism, were decisive in the transformation of the NS, leading to a radicalization of the party due to its endorsement of anti-Semitic and Nordic-racist attitudes. I will explain this argument briefly with a chronological summary of the findings from 1933 to 1936.

In 1933, the NS was an emerging party with a vague ideological direction. The aim was to unite a comprehensive political front against parliamentarism and communism. This aim was underpinned by a vague feeling of an economic, political and, most importantly, spiritual crisis which was to be resolved through national rebirth, inspired by both role models in Italy and Germany. Nonetheless, since its foundation, the NS emphasized in its press coverage that the party was a specific Norwegian national movement - independent from its two role models. Therefore, the idea of taking part in the ideological conflict between Hitler and Mussolini was from the beginning alien to the NS, since both countries were perceived to represent their own distinctive expression of a Europe-wide phenomenon, just as the NS constituted the Norwegian version of this phenomenon. Both role models were needed in the spiritual battle against the common enemies of the national movements: communism (in the NS press referred to as 'Marxism' and 'Bolshevism'), and liberalism (alternatively referred to as 'imperialism'). These enemies were defined as the old forces of materialism. In autumn 1935, this recurring argument in the NS press changed due to the reinterpretation of the materialist forces as instruments of the international Jewry.

At first, the party manifesto published in 1934 with its corporative character indicated a closer affinity of the NS to Italian Fascism. Noteworthy is the lack of anti-Semitic and radical racist positions in the program. Nonetheless, in summer 1934, Quisling himself admitted a closer affinity to Germany.

108 Brevig and de Figueiredo, Den norske fascismen, 19-110. 
In addition, German Nazism was not only a prevalent topic throughout the whole investigation period in the NS press, but was also strongly advocated. The outstanding example was the Night of the Long Knives, which the NS defended as a necessary measure to secure order in Germany. Quisling's involvement with CAUR, interpreted by scholars as an instrument to restore Italian ideological supremacy, did not challenge Germany's predominance in the NS press. Quisling objected to the dominance of both Italy and Germany in such an international organization in his speech given in Montreux in December 1934, thereby disclaiming the Italian idea of Universalità di Roma. According to Quisling, the organization was an instrument for peace and for mutual exchange between the different national movements in the battle against materialism. In addition, the Norwegian connection to the CAUR was Quisling's one-man-project. Large parts of the NS opposed the party leader's affiliation to the CAUR, which undermined the declared Norwegian independence.

The impact of the ideological rivalry between Italian Fascism and German Nazism was most apparent in autumn 1935. On the one hand, the ItaloEthiopian war brought estrangement between Italian Fascism and the NS. The influence of Nazi Germany on the other hand, became more and more obvious, illustrated by the increasing radical anti-Semitic tone in the NS press. In other words, in the battle over ideological supremacy, Nazi Germany won against Fascist Italy. This development was confirmed in 1936, when the NS press was increasing its admiration of national socialist ideas and events, praising Nazi Germany for being a nation of peace and order. Nonetheless, the rapprochement between Mussolini and Hitler was acclaimed in the NS press, because in the end, it confirmed that point that the NS had established in 1933: Fascism was regarded as an expression of the Italian version of the European phenomenon of national movements, Nazism as the German version, and the NS as the expression of the Norwegian national movement.

Therefore, the NS never prioritized the Italo-German rivalry as such. Instead, the party focused on its own national movement in the battle against its archenemies, while adopting ideas and learning from the two role models. However, in this transnational process of imitation, transfer, and transformation of political ideas during 1933-1936, Nazi Germany was the predominant force in the NS press. This is indicated by numerous positively connoted articles on internal German political events and developments, such as the German labor service, the Nuremberg rallies, the economic situation, the Kirchenstreit, German literature, etc. Italy on the other hand was almost exclusively reported on in the context of foreign relations. Even the most influential transfer from Italy to Norway, the idea of corporatism, was only imitated superficially, based 
upon the projection of Italian corporatism, and was soon transformed into a Norwegian version called Riksting.

On a methodological level, I argue that my paper demonstrates the usefulness of the transnational approach in the particular case of the Nasjonal Samling and for fascist studies in general. Especially noteworthy are three new findings: first the NS's self-conception as an independent Norwegian movement but within the community of kindred national movements; second the perception of the CAUR as an expression of these kindred national movements and therefore far more than a mere Italian power instrument; and third the direct German influence on the sudden increase of anti-Semitism in 1935, which supplements explanations offered by previous researchers. In the end, my research on the NS press, with its rapid change of topics and notions exemplified by the changing attitudes towards anti-Semitism, stresses the fluid and transformational character of smaller European fascist movements under the influence of German Nazism and Italian Fascism. Hence, the analysis underlines the advantage of utiliising the transnational approach to engage with Fascism's 'braided dynamics'. At least in the case of smaller European fascist movements, the transnational approach emerges as a promising tool for analyzing the destructive ideological notions that continue to challenge the ideas of democracy, human rights, and liberalism down to the present day. 